\title{
Bacterial diversity in an arctic lake: a freshwater SAR11 cluster
}

\author{
Michele Bahr ${ }^{1, *}$, John E. Hobbie ${ }^{1}$, Mitchell L. Sogin ${ }^{2}$ \\ ${ }^{1}$ The Ecosystems Center, ${ }^{2}$ Center for Molecular Evolution, Marine Biological Laboratory, Woods Hole, Massachusetts 02543, USA
}

\begin{abstract}
We used molecular techniques to assess the phylogenetic affinity of cultured and uncultured microorganisms from Toolik Lake, an oligotrophic lake in arctic Alaska, USA. The phylogenetic positions of cloned cultures of bacteria were determined by sequence analysis of PCR amplified ribosomal RNA genes. The Toolik Lake bacterial isolates showed a high degree of similarity, 0.94 to 0.99 , to a wide variety of phyla that are well represented in the ribosomal RNA database. The occurrence of species normally associated with a terrestrial habitat (Arthrobacter globiformis and Burkholderia solanacearum) or a more nutrient-rich environment (Cytophaga aquatilis and Zoogloea ramigera) suggests a particle-associated origin for these cell types, consistent with the fact that we used an unfiltered sample. In contrast, the analysis of rRNA genes cloned from a complex natural DNA community indicated the predominance of beta-proteobacteria closely related to the rRNA homology group II pseudomonads Alcaligenes eutrophus and Pseudomonas pickettii. However, 2 of the rRNA gene clones are deeply branching relatives (similarity $=0.88$ ) of the alpha-proteobacteria SAR11 cluster, previously detected only in marine environments. This finding indicates a widespread aquatic distribution for this recently described group.
\end{abstract}

KEY WORDS: Bacteria 16S rRNA · Arctic $\cdot$ SAR11

\section{INTRODUCTION}

Archaea and Bacteria are major agents of biogeochemical change in aquatic systems. The taxonomy of microbes is often based upon their physiological abilities, and taxonomic studies have the potential of providing a great deal of ecological information about the role of microbes in natural systems and ecological succession. There is a tremendous gap between taxonomy and ecology because microbial ecologists can only culture and identify a small percentage of the microbes in soils and water (Giovannoni et al. 1990, Ward et al. 1990, Schmidt et al. 1991, Barns et al. 1994). As a result, microbial ecologists have focused on a 'process approach' to study what prokaryotes collectively do in nature (Hobbie 1988). Laboratory-derived details of nutritional capabilities, requirements, and metabolic pathways which form the basis of microbial taxonomy have not been extended to consortia of species. The

•E-mail: mbahr@lupine.mbl.edu coupling of physiological information with identification of spatial and temporal species variation has the potential to provide micro- and macro-scale details on the flow of carbon and nutrients.

Molecular techniques provide an accurate means to determine the phylogenetic affinity of almost any microbial isolate, to detect the presence and phylogenetic affinity of organisms not amenable to standard laboratory cultivation, and to begin to chronicle environmental biodiversity. Such phylogenetic analysis not only extends our identification of naturally occurring picoplankton but, by comparison with cultured species, may also increase our understanding of their physiology as inferred from that of microbial taxa with very similiar rRNA genes. The phylogenetic characterization of small subunit rRNA genes (16S rRNAs; Pace et al. 1986) has gained widespread acceptance as a tool to understand microbial (and macrofaunal) speciation in marine systems (Giovannoni et al. 1990, Britschgi \& Giovannoni 1991, Schmidt et al. 1991, DeLong 1992, DeLong et al. 1993, Fuhrman et al. 1993, Mullins et al. 1995) and in extreme environments (Ward et al. 1990, 
Barns et al. 1994). Ribosomal RNA probes have delin eated marine microbial succession (Rehnstam et al. 1993). Similar studies of picoplankton from oligotrophic freshwater environments have not been reported.

Here we report 2 molecular characterizations of the microbial community from Toolik Lake, Alaska, USA, an arctic Long Term Ecological Research (LTER) site. We relied upon differences in $16 \mathrm{~S}$ rRNA to differentiate between cultured bacteria that we grouped accord ing to shared phenotypic attributes. We used similar molecular methods to characterize the rRNA genes and thus the biodiversity of a concentration of bacterial cells collected from Toolik Lake. This provided a comparison between the cultured cells and the total population of bacteria, most of which have yet to be cultured. Comparison of these species to those described from other environments pointed to a high degree of similarity with both temperate freshwater and, surprisingly, subtropical marine systems.

\section{MATERIAL AND METHODS}

Site description. Toolik Lake $\left(68^{\circ} 38.0^{\prime} \mathrm{N}, 149^{\circ}\right.$ $36.25^{\prime} \mathrm{W}$ ) is an oligotrophic, multiple basin kettle lake located at $720 \mathrm{~m}$ elevation about $20 \mathrm{~km}$ north of the Brooks Range, Alaska. The lake has a surface area of 149 ha with a maximum depth of $25 \mathrm{~m}$ and a mean depth of $7 \mathrm{~m}$. The major inflow comes in the spring from snowmelt; there are approximately 90 ice-free days per year. DOC (dissolved organic carbon) is typically $575 \mu_{\mathrm{mol} \mathrm{l}}^{-1}$ (O'Brien et al. 1996). The numbers of bacteria in the water column, measured by direct count, range from 0.5 to $1.5 \times 10^{6} \mathrm{ml}^{-1}$ (Hobbie et al. 1978).

Cell isolation and DNA extraction. Toolik Lake main station water $(500 \mathrm{ml})$ was filtered through acidwashed $0.2 \mu \mathrm{m}$ filters (Millipore) in July, 1992. There was no pre-filtration to limit the size fraction of the retained cells. The filters were incubated at ambient lake temperature, $15^{\circ} \mathrm{C}$, in the dark on agar plates. The medium was designed to select a variety of heterotrophic organisms from an oligotrophic environment (Reasoner \& Geldreich 1985). A total of 66 individual colonies were isolated and transported to the Marine Biological Laboratory (Woods Hole, MA, USA) in stab vials. The isolates were re-grown, examined microscopically, and grouped by cell and colony appearance into 11 morphological types. A representative of each type was grown to high density on plates. The colonies were then transferred to culture tubes and washed twice with $1 \mathrm{ml}$ sterile wash solution $[80 \% \mathrm{ETOH}$, $145 \mathrm{mM} \mathrm{NaCl}, 50 \mathrm{mM}$ Tris-Cl, pH 8.0, 0.05\% Nonidet P-40 (Sigma)]. Following centrifugation, the cell pellets were suspended in $40 \mu \mathrm{ll} 10 \mathrm{mM}$ Tris $-\mathrm{Cl}_{1} \mathrm{pH} 8.3$ and $\mathrm{KOH}$ added to a final concentration of $0.2 \mathrm{~N}$ The cells were heated to $70^{\circ} \mathrm{C}$ and monitored for cell lysis. After 15 to 30 min, the solution was neutralized with an equal volume of $1 \mathrm{~N} \mathrm{HCl}$ mixed $2: 1$ with $1 \mathrm{M}$ Tris-Cl ( $\mathrm{pH}$ 8.3), centrifuged, and the supernatant transferred to microfuge tubes for subsequent amplification (Angert et al. 1993).

Cell concentration and DNA extraction. In July, 1994, 40 l of Toolik Lake main station water was prefiltered through a sterile $1 \mu \mathrm{m}$ polysulfone cartridge (Whatman). The cells in the supernatant were concentrated into $1200 \mathrm{ml}$ using a $30 \mathrm{kDa}$ cutoff polysulfone hollow-fiber filter in a DC-10L filtration unit cleaned according to the manufacturer's directions (Amicon, Beverly, MA). Prior to this concentration: this hollowfiber filter was used 3 times with Toolik Lake water. The concentrate was stored frozen for transport to Woods Hole. After rapid thawing, centrifugation at $10000 \times g$ for $30 \mathrm{~min}$, and suspension in $5 \mathrm{ml} \mathrm{TE}$ (10 mM Tris, 1 mM EDTA, pH 8.0), the cells were lysed in a French press following the manufacturer's directions (SLM Instruments, Urbana, IL, USA). This method was chosen to avoid enzymatic degradation of DNA. The lysate was phenol extracted; the nucleic acids were precipitated in ethanol, centrifuged, and suspended in $200 \mu \mathrm{l}$ TE buffer.

PCR amplification and gene cloning. For both the isolates and the mixed community concentrate, $16 \mathrm{~S}$ ribosomal DNA was amplified using universal primers with polylinker tails, 515 FPL (GCGGATCCTCTAGACTGCAGTGCCAGCAGCCGCGGTAA) and 1492 RPL (GGCTCGAGCGGCCGCCCGGGTTACCTTGTTACGACTT). First, 0.01 to $1.0 \mu$ DNA template (not quantified) was added to $30 \mathrm{mM} \mathrm{KCl}, 10 \mathrm{mM}$ Tris $-\mathrm{Cl}$, $1.5 \mathrm{mM} \mathrm{MgCl}_{2}, 0.05 \%$ Nonidet P-40, $0.2 \mu \mathrm{g}$ of each primer, $1.25 \mathrm{mM}$ each dATP, dCTP, dGTP and dTTP, $5 \%$ acetamide and 1 unit Taq polymerase. Thermal cycling was carried out at $92^{\circ} \mathrm{C}$ for $1.5 \mathrm{~min}, 37^{\circ} \mathrm{C}$ for $1.5 \mathrm{~min}$, and $72^{\circ} \mathrm{C}$ for 2 min for 30 cycles. The PCR products were phenol extracted, precipitated in ethanol and suspended in $10 \mu \mathrm{l}$ TE. The rDNA was checked for internal restriction sites, cut and ligated into the Pstl and Xhol sites of the pBluescript plasmid, which was then used to transform competent Escherichia coli strain XL-1 Blue. The plasmid DNA was extracted and purified using Promega Wizard (Promega, Madison, WI, USA) DNA clean-up columns for manual ${ }^{35} \mathrm{~S}$ sequencing, or Qiagen columns (Qiagen Inc., Chatsworth, CA, USA) for machine-based sequencing following the manufacturer's protocols.

Sequencing and phylogenetic analysis. The DNA from the isolates was denatured and sequenced using the dideoxynucleotide chain-termination method with Sequenase 2.0 following the manufacturer's recom- 
mendations (United States Biochemical, Cleveland $\mathrm{OH}, \mathrm{USA}$ ). The sequences were aligned with a subset of 475 bacteria species from the Ribosomal Database Project (RDP; Maidak et al. 1996).

For the DNA from the community concentrate, we used a single dideoxynucleotide chain-termination sequencing reaction to initially sort rRNA genes cloned from PCR amplifications. A full sequence analysis on both strands was done using SequiTherm thermal cycle sequencing with the incorporation of infrared labeled primers (Epicentre Technologies Madison. WI, USA). Reaction products were electrophorised on a model 4000L automated DNA sequencer (LiCor, Lincoln, NB, USA). We employed a computer-assisted multiple alignment editor to align the sequences with $>2000$ bacterial species archived in the RDP (Maidak et al. 1996). Sequences were submitted to the CHECK_CHIMERA program of the RDP to detect the presence of possible chimeric artifacts. The phylogenetic relationships were inferred by the distance matrix analysis (Olsen 1988) of 765 unambiguously aligned positions between bases 515 and 1492, Escherichia coli numbering system, and included both conserved and hypervariable regions of the gene. Detailed phylogenetic analyses were restricted to species that were at least 0.77 similar to the unknown microorganisms. Bootstrap methods were used to provide confidence estimates for the tree topologies (Felsenstein 1985). The determined nucleotide sequences will appear in the GenBank Database under the accession numbers U76088 to U76105.

\section{RESULTS}

The isolates cultured from mid-summer Toolik Lake water in 1992 were grouped into 11 phenotypes on the basis of cell and colony morphology. We successfully amplified 16S rRNA genes from 9 of the 11 representatives. One of the amplicons contained an internal restriction site for PstI and/or XhoI which confounded cloning. To identify their approximate phylogenetic positions in a rRNA framework, we determined partial rRNA sequences ( -500 base pairs) for 7 isolates. The resulting identifications showed a high degree of similarity, at least 0.94 , with known temperate species representing a variety of phyla (Table 1). Identification using the RDP is necessarily limited to those species previously sequenced and catalogued in the database. Although sequence similarity of rRNA gene clones is not an absolute measure of species identity, molecular systematics can establish the closest known relative to the organism of interest. For example, an average similarity of 0.86 separates representatives of genera in the beta subclass of Pseudomonas from each other ( $\mathrm{Li}$
Table 1 Survey of Toolik Lake isolates. Gene clones were constructed from bacteria cultures. Related species and similarity to the clones were calculated by comparison with $16 \mathrm{~S}$ rRNA sequences archived in the Ribosomal RNA Database Project (RDP)

\begin{tabular}{|clc|}
\hline $\begin{array}{c}\text { Clone } \\
\text { identification }\end{array}$ & \multicolumn{1}{c}{ Related species } & Similarity \\
\hline 1 & Burkholderia solanacearum & 0.987 \\
5 & Acinetobacter calcoaceticus & 0.943 \\
11 & Arthrobacter globiformis & 0.966 \\
18 & Cytophaga aquatilis & 0.994 \\
32 & Cytophaga aquatilis & 0.990 \\
19 & Pseudomonas mendocina & 0.965 \\
21 & Zoogloea ramigera & 0.975 \\
\end{tabular}

et al. 1993). The isolation method selected for aerobic heterotrophs, and those cultured represent distinct branches of Bacteria. The phylogenetic relationships of the Toolik isolates and related species in Table 1 are depicted in the Fig. 1 tree of selected Bacteria. The only Gram-positive species in Table 1, Arthrobacter globiformis, is frequently a dominant constituent of the soil microbial community and grows on a variety of substrates. Of the Gram-negative species in Table 1, the single flavobacterium is Cytophaga aquatilus, a gliding organotroph capable of degrading biomacromolecules. The other species in Table 1 are proteobacteria of the beta and gamma subclasses. Of the betaproteobacteria, Burkholderia solanacearum is a plant pathogen and Zoogloea ramigera reduces nitrate in eutrophic environments. Of the gamma-proteobacteria, Pseudomonas mendocina is a RNA homology Group I non-fluorescent species found in soil and water. This species degrades low molecular weight organic compounds. The major biochemical feature of Acinetobacter calcoaceticus is its ability to metabolize a wide range of compounds including relatively recalcitrant aromatics.

Overall, the species represented in Table 1 are both ubiquitous and abundant worldwide (Balows et al. 1992). The occurrence of species normally associated with a terrestrial habitat (Arthrobacter globiformis and Burkholderia solanacearum) or a more nutrient-rich environment (Cytophaga aquatilis and Zoogloea ramigera) suggests a particle-associated origin for these cell types, consistent with the fact that we used an unfiltered sample.

For the molecular survey of the community of microorganisms, we concentrated cells $<1 \mu \mathrm{m}$ in size from a 1994 mid-summer collection of Toolik water. The pre-filtration eliminated most particle-associated or aggregated cells. Microscope examination confirmed that this sample was effectively restricted to the free-living picoplankton. Following PCR amplification 


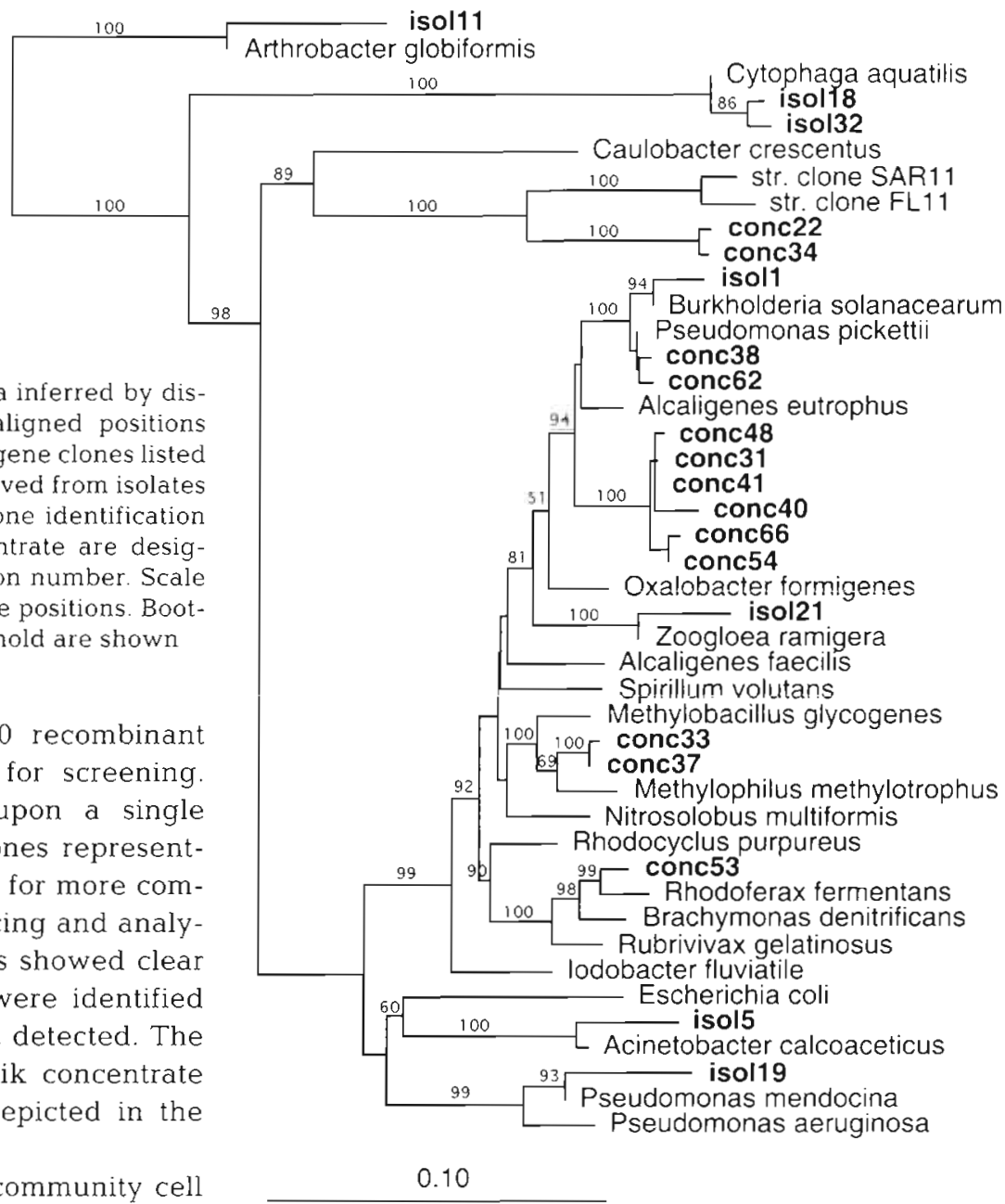

Fig. 1. Phylogenetic tree of selected Bacteria inferred by distance matrix analysis of unambiguously aligned positions within 16S rRNA gene sequences. All of the gene clones listed in Tables $1 \& 2$ are included. The clones derived from isolates are designated 'isol' followed by a gene clone identification number; those from the community concentrate are designated 'conc' followed by a gene identification number. Scale indicates 10 base changes per 100 nucleotide positions. Bootstrap values which exceeded a $50 \%$ threshold are shown

for $16 \mathrm{~S}$ rRNA genes and cloning, 60 recombinant Escherichia coli clones were picked for screening. Using our low-level survey based upon a single nucleotide sequencing reaction, 13 clones representing divergent sequences were selected for more complete analysis. Subsequent full sequencing and analysis of 800 to 900 bases of the 13 clones showed clear differences but only 5 gene clusters were identified (Table 2). No chimeric sequences were detected. The phylogenetic relationships of the Toolik concentrate clones and related species are also depicted in the Fig. 1 tree of selected Bacteria.

All rRNA genes amplified from the community cell concentrate were identified as proteobacteria; 11 of the 13 were members of the beta-proteobacteria. Among the beta-proteobacteria in Table 2 is Pseudomonas pickettii, normally a plant pathogen. The most frequently recovered Toolik Lake gene clone cluster (clones 31, 40, 41, 48, 54 and 66) branches nearby; these are most closely related to Alcaligenes eutrophus. A eutrophus is a facultative chemolithoautotrophic hydrogen-oxidizing bacteria. The 'knallgas' bacteria are capable of growing on either organic substrates or on hydrogen plus carbon dioxide. In A. eutrophus, the $\mathrm{H}_{2}$-oxidation capacity is plasmid-linked. The aerobic methylotrophic group is represented in Table 2 by Methylophilus methylotrophus (Balows et al. 1992). Another beta-proteobacterium in Table 2 is Rhodoferax fermentans, a facultatively anaerobic photoorganotroph able to grow by either photosynthesis and aerobic respiration or anaerobic-dark fermentation (Hiraishi et al. 1991).

Clones 22 and 34 listed in Table 2 are related to the alpha-proteobacteria cluster SAR11. Fig. 2 shows a phylogenetic tree which focuses on the alpha-proteobacteria. Gene clones 22 and 34 are deeply branching

Table 2. Survey of the Toolik Lake microblal community. Gene clones were constructed from a bacteria cell concentration. Related species and similarity to the clones were calculated by comparisons of $16 \mathrm{~S}$ rRNA archived in the RDP

\begin{tabular}{|clc|}
\hline $\begin{array}{c}\text { Clone } \\
\text { identification }\end{array}$ & \multicolumn{1}{c|}{ Related species } & Similarity \\
\hline 22 & SAR11 & \\
34 & SAR11 & 0.897 \\
31 & Alcaligenes eutrophus & 0.884 \\
40 & Alcaligenes eutrophus & 0.950 \\
41 & Alcaligenes eutrophus & 0.941 \\
48 & Alcaligenes eutrophus & 0.953 \\
54 & Alcaligenes eutrophus & 0.949 \\
66 & Alcaligenes eutrophus & 0.945 \\
38 & Pseudomonas pickettii & 0.993 \\
62 & Pseudomonas pickettii & 0.994 \\
33 & Methylophilus methylotrophus & 0.968 \\
37 & Methylophilus methylotrophus & 0.970 \\
53 & Rhodolerax fermentans & 0.978 \\
& & \\
\hline
\end{tabular}


with the SAR11 cluster in that tree (similarity $=0.88$ ); this relationship is supported by a bootstrap value of $98 \%$. The alignment used for the Fig. 2 phylogenetic tree included environmentally-derived sequences from the Atlantic Sargasso Sea and Bermuda Stations and free-living bacterioplankton off the California coast. The physiology and ecological function of the SAR11 group is not presently understood (Mullins et al. 1995).

Nucleotide signature analysis of the Toolik clone 22 sequence shows that 13 of the 17 signature sequences which distinguish alpha-proteobacteria (Woese et al. 1965) are conserved in this sequence. Two of the signature sequences not present (610 and 675) are found in only 39 and $65 \%$ of the alpha proteobacteria, respectively. Two other signature sequence divergences (795 and 910) are shared with SAR11. Like other clones in the SAR11 cluster, e.g. SAR95, FL1 and FL11, Toolik clones 22 and 34 do not contain the BamH1 restriction site at position 1190 which characterizes SAR11 and SAR1.

The secondary structure of Toolik clone 22 and SAR11 was compared to that of the alpha-proteobacterium Agrobacterium tumefaciens. Base substitutions are localized in variable regions, with $50 \%$ of the Toolik clone 22 base substitutions having compensating base changes across helices, while $20 \%$ of the changes occur in loops (data not shown). Toolik clone 22 substitutions occurring between bases 998 and 1046 show particularly close similarity to base changes in SAR11; 24 of the 29 base substitutions within this region of the molecule are identical. Although only half of the 16S RNA molecule was analyzed in this study, these data demonstrate that the divergence of the SAR11 cluster from the alpha-proteobacteria lineage corresponds to a base composition shift towards a lower GC content (Agrobacterium tumefaciens 55\%, Toolik clone $2249 \%$, SAR11 47\%).

When clones of the cultured isolates were compared with the mixed community concentrate, only 1 closely related gene clone was found in both sets. Isolate gene clone 1 was similar to the Alcaligenes eutrophusPseudomonas pickettii-Toolik concentrate cluster (Fig. 1). A phylogenetic study of rRNA homology group II pseudomonads (Li et al. 1993) detailed the similarity of the $A$. eutrophus- $P$. pickettii- $P$. solanacearum cluster.

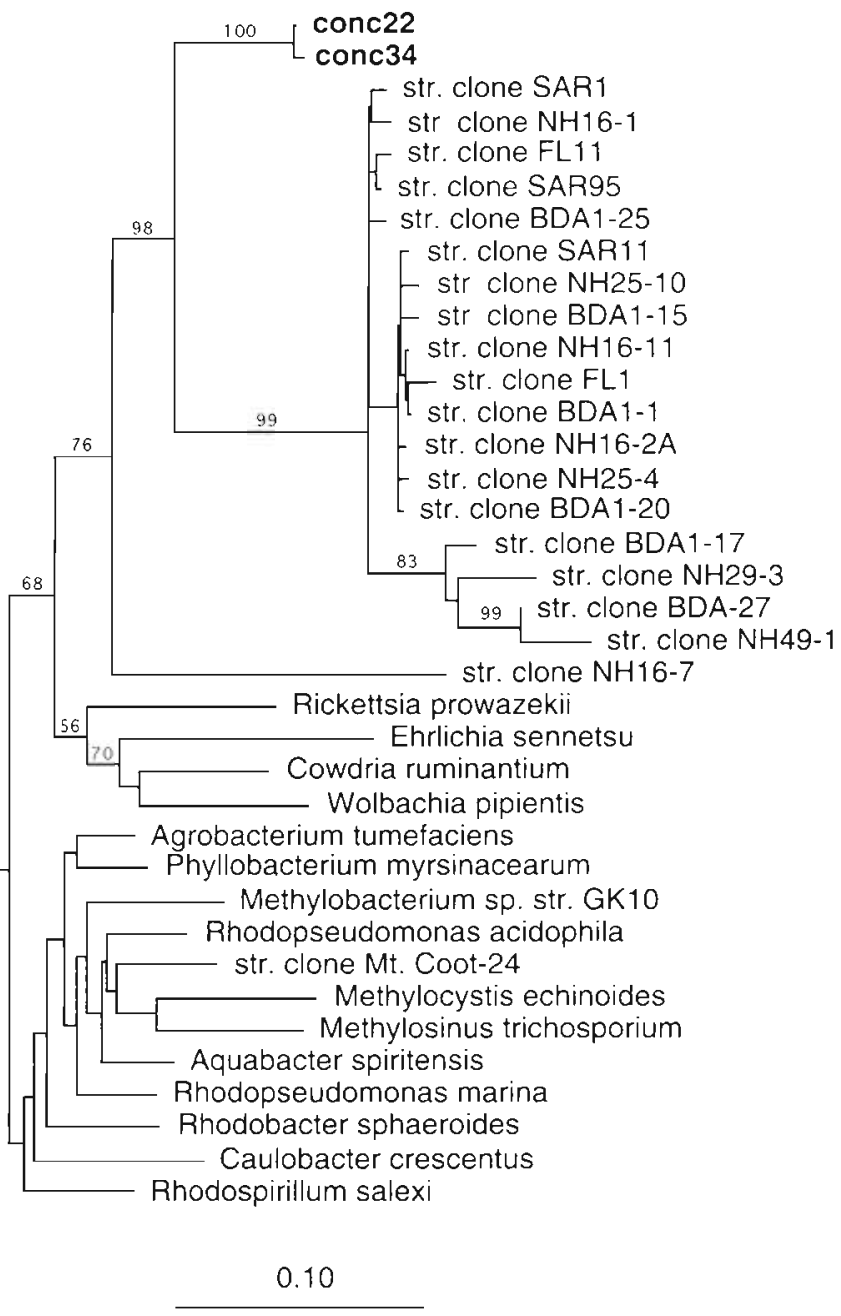

Fig. 2. Phylogenetic tree of alpha-proteobacteria at least 0.77 similar to Toolik Lake clones 22 and 34 . The tree was inferred by distance matrix analysis of 765 unambiguously aligned positions within $16 \mathrm{~S}$ rRNA gene sequences with the exception of $\mathrm{BD}$ and $\mathrm{NH}$ clones of which $<200$ positions are published. Escherichia coll was used as an outgroup to root the tree. Closely related genotypes include SAR (clones from the Sargasso Sea), FL (clones from free-living bacterioplankton off the California coast), BD (clones isolated of the Bermuda coast at $10 \mathrm{~m}$ ) and $\mathrm{NH}$ (clones isolated from the northeastern Pacific Ocean at $100 \mathrm{~m}$ and $500 \mathrm{~m}$ ). Scale indicates 10 base changes per 100 nucleotide positions. Bootstrap values which exceeded a $50 \%$ threshold are shown

Focusing on the sequences of its nearest neighbors, we found gene clone 1 to be most closely related to Burkholderia solanacearum (similarity $=0.987$ ).

\section{DISCUSSION}

This work provides a first order estimate of diversity within an arctic freshwater ecosystem. Our first set of isolates demonstrate that the previously uncharacterized Toolik Lake bacterioplankton are neither mono- 
phyletic nor unique. A variety of phyla potentially capable of metabolizing a wide range of compounds were cultured. Apparently arctic conditions are not so extreme as to exclude adaptation by species which inhabit more temperate environs. Analysis of physiological information available on closely related species leads one to expect a wide range of compounds to be transformed by the lake microbes. Concomitant chemical studies are under way to characterize the dissolved organic matter entering the lake (data not presented).

Bacteria exhibit wide-ranging metabolic and phylogenetic diversity, yet display little variation in phenotype. Additionally, the nutritional requirements of microorganisms from natural systems are largely unknown and most microorganisms remain uncultured. Our preliminary study began by grouping bacterial isolates according to morphological features; this approach undoubtedly constrained our assessment of the total lake population. Consequently, our second sampling focused on a cell concentrate of the total picoplankton community and enabled comparison between those types that we had cultured and the community components.

We expected greater diversity within the community concentrate DNA sample than among the cultures. Any cryptic variants were not detected by our initial screening, which relied on differences within a single nucleotide. Although none of the 13 clones sequenced following screening were identical, only 5 phylogenetic clusters were identified within the community. A potential loss of genotypes can occur at a number of stages in a phylogenetic survey. DNA can be degraded during thawing of frozen field samples or as a result of enzymatic activity. PCR bias may result in a skewed amplification of sequences or cloning may select for PCR products. On the other hand, we may not have successfully cultivated the most common Toolik Lake bacteria, but a diverse array of more rare species. The possibility also exists that the cell concentration detected the occurrence of a low diversity bacterial 'bloom' at the time of sampling. If this is, in fact, a bloom of Alcaligenes eutrophus relatives, it is our first indication of which organisms are involved in microbial succession in the lake. Molecular microbial identification via $16 \mathrm{~S}$ rRNA probes capable of tagging individual cells would be of great use to determine it the full range of Toolik Lake microbes have been represented, or if this is indicative of the spatial and temporal changes in microbial community composition that are assumed to be an inherent feature of environmental biogeochemistry. In a study designed to track microbial succession along the California coast, Rehnstam et al. (1993) reported that a single genotype accounted for $100 \%$ of the microorganisms at 1 sampling date.
Within the Toolik community of bacteria $<1 \mu \mathrm{m}$ size, we found a preponderance of closely related beta-proteobacteria. This is in contrast to some oceanic surveys which have differentiated a myriad of gcnotypes (Fuhrman et al. 1993). The Toolik Lake assemblage may fall into a more cohesive set and therefore be more amenable to defining key microbial groups. To accurately determine diversity, dominance, and succession within the lake community we would have to amplify the DNA from many more cells throughout the year. These water samples were taken in mid-July at a time of lake stratification. Samples taken from under the ice and during periods of thorough mixing would provide a more complete picture of the microbial population and its seasonal fluctuations. Several of the species identified so far are typically associated with soil communities. Utilization of molecular probes within a more extensive sampling framework could clarify the source of the populations and whether they are transient soil organisms which have been washed in or autochthonous lake species, either of which may be associated with particles. Comparative phylogenetic analysis is one way of obtaining information on the specific components involved in carbon utilization pathways and on controls of decomposition of particulate and dissolved organic matter. This identification may also enable us to deduce some of the controls on these populations.

Molecular population surveys in the ocean have detected an extensive array of cyanobacteria and proteobacteria of the alpha and gamma subgroups. In our initial population survey, the dominant clones were also proteobacteria, but of the alpha and beta subgroups. An unexpected result of our work was the presence of gene clones related to the SAR11 cluster, a group first described in 1990. The SAR11 cluster has been found in Atlantic and Pacific open ocean water and off the Florida, Bermuda and California (USA) coasts, but not along the Oregon (USA) coast (Giovannoni et al. 1990, Schmidt et al. 1991). It has been regarded as a subtropical marine group. The presence of a deeply branching relative in an arctic freshwater system indicates that this recently detected lineage has radiated throughout large salinity and temperature ranges. Its far-reaching adaptation raises questions as to its ecologicai roie. Át inis puini, we are onlyy able to document its distribution. Clearly there are gaps in our knowledge of biodiversity and biogeography. The data available do not allow an estimate of the true diversity because differences in the efficiency of DNA extraction, amplification or cloning may occur among species. With this caveat, molecular-based ecological studies such as this go beyond the constraints of cultivation and are just beginning to describe naturally occurring microorganisms. 
Note added in proof. In the 'Introduction', we stated that 'similar studies of picoplankton from oligotrophic freshwater environments have not been reported'. However, one study has been published since this article was submitted: Alfreider A, Pernthaler J, Amann R, Sattler B, Glockner FO, Wille A, Psenner $R$ (1996) Community analysis of the bacterial assemblages in the winter cover and pelagic layers of a high mountain lake by in situ hybridization. Appl Environ Microbiol 62:2138-2144

Acknowledgements. M.B. thanks the Center for Molecular Evolution group for their generous laboratory and computer assistance. This work was supported by the National Science Foundation Division of Environmental Biology (grant number 9211775 to J.E.H.) and Office of Polar Programs (grant number 9400722 to J.E.H.), the G. Unger Vetleson Foundation, and the National Institutes of Health (grant number GM32964 to M.L.S.).

\section{LITERATURE CITED}

Angert ER, Clements KD, Pace NR (1993) The largest bacterium. Nature 362:239-241

Balows A, Truper HG, Dworkin M, Harder W, Schleifer KH (eds) (1992) The prokaryotes. Springer-Verlag, New York

Barns SM, Fundyga RE, Jeffries MW, Pace NR (1994) Remarkable archael diversity detected in a Yellowstone National Park hot spring environment. Proc Natl Acad Sci USA 91: $1609-1613$

Britschgi TB, Giovannoni SJ (1991) Phylogenetic analysis of a natural marine bacterioplankton population by rRNA gene cloning and sequencing. Appl Environ Microbiol 57 : $1707-1713$

DeLong EF (1992) Archaea in coastal marine environments. Proc Natl Acad Sci USA 89:5685-5689

DeLong EF, Franks DG, Alldredge AL (1993) Phylogenetic diversity of aggregate-attached vs. free-living marine bacteria assemblages. Limnol Oceanogr 38:924-934

Felsenstein H (1985) Confidence limits on phylogenies: an approach using the bootstrap. Evolution 39:783-791

Fuhrman JA, McCallum K Davis AA (1993) Phylogenetic diversity of subsurface marine microbial communities from the Atlantic and Pacific Oceans. Appl Environ Microbiol 59:1294-1302

Giovannoni SJ, Britschgi TB, Moyer CL Field KG (1990) Genetic diversity in Sargasso Sea bacterioplankton.

Responsible Subject Editor: J. Fuhrman, Los Angeles, California, USA
Nature 345:60-63

Hiraishi A, Hoshino Y Satoh T (1991) Rhodoferax fermentans gen. nov., sp. nov., a phototrophic purple nonsulfur bacterium previously referred to as the Rhodocyclus gelatinosus-like' group. Arch Microbiol 155:330-336

Hobbie JE (1988) A comparison of the ecology of planktonic bacteria in fresh and salt water Limnol Oceanogr 33: 750-764

Hobbie JE, Corliss TL, Peterson BJ (1978) Seasonal patterns of bacterial abundance in an arctic lake. Arct Alp Res 15: 253-259

Li X. Dorsch M, Del Dot T, Sly LI, Stackebrandt E, Hayward AC (1993) Phylogenetic studies of the IRNA group II pseudomonads based on $16 \mathrm{~S}$ rRNA gene sequences. J Appl Bacteriol 74:324-329

Maidak BL, Olson GC, Larsen N, Overbeck R, McCaughey MJ, Woese CR (1996) The Ribosomal Database Project (RDP). Nuc Acids Res 24:82-85

Mullins TD, Britschgi TB, Krest RL, Giovannoni SJ (1995) Genetic comparisons reveal the same unknown bacterial lineages in Atlantic and Pacific bacterioplankton communities. Limnol Oceanogr 40:148-158

O'Brien WJ, Bahr M, Hershey A, Hobbie J, Kipphut G, Kling G, Kling H, McDonald M, Miller M, Rublee P, Vestal R (1996) The limnology of Toolik Lake. In: Osgood M, Milner $S$ (eds) Freshwaters of Alaska. Springer-Verlag. New York, p 61-106

Olsen GJ (1988) Phylogenetic analysis using ribosomal RNA. Meth Enzymol 164:793-812

Pace NR, Stahl DA, Lane DJ, Olsen GJ (1986) The analysis of natural microbial populations by ribosomal RNA sequences. Adv Microb Ecol 9:1-55

Reasoner DJ, Geldreich EE (1985) A new medium for the enumeration and subculture of bacteria from potable water. Appl Environ Microbiol 49:1-7

Rehnstam A, Backman S, Smith DC, Azam F, Hagström A (1993) Blooms of sequence-specific culturable bacteria in the sea. FEMS Microbiol Ecol 102:161-166

Schmidt TM, DeLong EF, Pace NR (1991) Analysis of a marine picoplankton community by $16 \mathrm{~S}$ rRNA gene cloning and sequencing. J Bacteriol 173:4371-4378

Ward DM, Weller R, Bateson MM (1990) 16S rRNA sequences reveal numerous uncultured microorganisms in a natural community. Nature 345:63-65

Woese CR, Stackebrandt E, Macke TJ, Fox GE (1965) A phylogenetic definition of the major eubacterial taxa. Syst Appl Microbiol 6:143-151

Manuscript first received: June 6, 1996

Revised version accepted: September 23, 1996 